\title{
Overview of China's Automotive Tax Scheme: Current Situation, Potential Problems and Future Direction
}

\author{
Liu Zongwei, Wang Yue, Hao Han and Zhao Fuquan \\ Tsinghua Automotive Strategy Research Institute, State Key Laboratory of Automotive Safety and \\ Energy, Beijing, China
}

Correspondence should be addressed to: Wang Yue; wangyue3692@126.com

Received date: 24 January 2017; Accepted date: 22 May 2017 ; Published date: 22 December 2017

Academic Editor: Kamilah Ahmad

Copyright (C 2017. Liu Zongwei, Wang Yue, Hao Han, Zhao Fuquan . Distributed under Creative Commons CC-BY 4.0

\begin{abstract}
Automotive industry acts as a pillar industry in national economy and plays a key role in China's manufacturing industrial upgrading. Meanwhile, taxation is the essential economic leverage for the government to impose macro-control over the market. In view of this, China's tax scheme on domestic automotive industry was examined thoroughly and the corresponding impacts were analyzed through case study, scenario analysis and international comparison. It was found that China's automotive tax scheme has inadequate influence on the market concerning energy conservation and emission reduction, with limited incentives posed to low-engine-displacement vehicles. Besides, China's automotive tax is over-assigned to producing and purchasing phases and the tax revenue distribution pattern is not reasonable as well. Therefore, adjustment in automotive tax scheme is of vital importance in the future to pursue a sustainable development. It is suggested and prospected that China's automotive tax scheme be reformed in several aspects, including giving more preferences to low-engine-displacement vehicles, balancing taxes well in different phases, putting principles of 'ownership encouraged and usage rationalized', 'earmarking taxes' and 'burdening beneficiaries' into practice.
\end{abstract}

Keywords: automotive industry, taxation reform, energy conservation, emission reduction

Cite this Article as: Liu Zongwei, Wang Yue, Hao Han, Zhao Fuquan (2017)," Overview of China's Automotive Tax Scheme: Current Situation, Potential Problems and Future Direction", Journal of Southeast Asian Research, Vol. 2017 (2017), Article ID 790677, DOI: 10.5171/2017. 790677 


\section{Introduction}

Currently China is at the initial and vital stage of achieving the strategic planning of 'China Manufacturing 2025'. Accordingly, automotive industry encounters significant and historical opportunities of transformation and upgrading, with energy-saving vehicles, new energy vehicles (NEV) and intelligent connected vehicles listed as one of the ten key areas. Taxation reform of China's automotive industry is of vital importance to support the realization of the strategic target of a stronger automotive country, and the setup of a healthy and sustainable automotive society. Therefore, it is necessary to analyze China's current automotive tax scheme thoroughly to see whether it is reasonable, so as to find out potential problems and provide further suggestions, with the aim of comprehensive optimization of future automotive taxation.

From the perspective of microeconomics, taxation has influence on the market demand structure and corporates' production planning. For example, preferential taxation played a vital role in the rapid rebound of China's automotive industry after the financial crisis in 2008. In 2009, the State Council of China implemented a plan on adjusting and revitalizing the automotive industry formulating Vehicle Purchase Tax (VPT) rate of passenger vehicles (PV) with $1.6 \mathrm{~L}$ displacement or below, which was reduced from $10 \%$ to $5 \%$. With this policy in effect, data from China Association of Automobile Manufacturers (CAAM) shows that in 2009, sales volume of PVs with 1.6L displacement or below reaches 7.2 million units, with $71.3 \%$ year-on-year growth, and occupies $69.7 \%$ of total PV sales rising by eight percentage points (CAAM, 2010). On the other hand, compared with administrative means and fiscal subsidies, appropriate tax scheme is a normal market-oriented economic approach, as well as a longerlasting approach to avoid possible market rebound after subsidy cancelling.
Studies on China's automotive taxation have increased gradually since the 1990s. Yuan first sort out the detailed influences of taxation adjustment in automotive industry such as tariff policy adjustment, value-added tax (VAT) transformation pilot program and consumption tax (CT) adjustment (2008). From a historical perspective, Chen and Zhou concluded that the existing tax scheme is still not reasonable (2010). Specifically, it was pointed out that levying vehicle CT by displacement in China is not a good practice (Xiao, 2008), and there are functional overlaps in VPT and vehicle CT (Liu and Liu, 2010).

With stricter fuel economy regulations and more adoption of green vehicles, traditional fuel-tax-based revenue in the United States is expected to be reduced by more than 37\% in 2025 (Vasudevan and Nambisan, 2013), which is no longer sustainable to finance transportation outcome. As a possible replacement, vehicle-miles-traveled (VMT) tax has been proposed and studied (McMullen et al., 2010; Parry and Small, 2005; Duncan and Graham, 2013). Furthermore, a comprehensive tax system including both local congestion pricing and an indexed roadway user toll on energy efficiency would generate the same level of revenue as VMT, together with reducing greenhouse gas emissions and petroleum dependence (Greene, 2011). However, it is quite a different situation in China. The exact fuel tax (FT) category has not been established while CT on refined oil function partly as FT, which was clearly objected (Liu and Liu, 2010). Similarly, limitation and incentive mechanism of tax policy was applied to argue that FT reform is the strategic direction of energy conservation and emission reduction in road transportation section (Li and Wang, 2009).

In addition, there exist many social concerns with automotive use. Traffic congestion was one of the earliest issues clearly evaluated and several strategic analyzing methods were put up (Downs, 2000). A framework for traffic congestion 
management was proposed, among which appropriate taxation is one important part in demand side measures (Talukdar, 2013). From theoretical level, the public automotive consumption can be directed to relieve vehicle-road conflict and benefit energy saving by taxation (Li, 2009), which was previously proved (Lian and He, 2005).

It can be seen that taxation in automotive industry has been broadly studied from diverse perspectives and most of which fully affirm taxation's market adjustment effects. Most studies pitched in from individual tax and proposed tax scheme adjustment suggestions in detail. However, few studies did comprehensive analysis and overall judgment on rationality of China's automotive tax scheme, which is the goal of this study. Automotive tax scheme is defined in this paper as the regime covering all levied taxes throughout the full life cycle of a vehicle, namely the production to the purchase, retainment and usage. Recycling is still under development in China, thus this study will not include recycling phase in. There are two principles to evaluate the rationality of tax scheme: one is whether it is beneficial for facilitating the healthy and sustainable development of the industry and setting up a harmonious automotive society to ease relevant constraints fundamentally; the other is whether it is beneficial for setting up a stronger automotive country. This paper focuses on taxes in full life cycle of PV manufactured in China, and includes various taxes with significant revenues levied on automakers and consumers, but does not include taxes for vehicle dealers, maintainers and used car dealers at selling and aftersales phases. The following sections include analysis on current China's automotive tax scheme, case study and scenario analysis on PV tax burden, and tax distribution mechanism with related issues, together with comparison of tax schemes in major countries to generate relevant enlightenments. Based on all these above, solutions to optimize China's automotive tax scheme are proposed.

\section{China's Current Automotive Tax Scheme}

Tax revenue in automotive industry is huge in total. VPT, the domestic VAT, enterprise income tax (IT) and CT are the major sources, bringing tax revenue of $¥ 288.5$ billion ( $\$ 47$ billion based on exchange rate of August, 2015, the same hereinafter), $¥ 154.2$ billion ( $\$ 25$ billion), $¥ 101.0$ billion ( $\$ 16$ billion) and $¥ 93.4$ billion ( $\$ 15$ billion) respectively in 2014 (SAT, 2015). Clearly automotive industry contributes significantly to central and local governments' financial revenue. With levying phase as the major distinguishing dimension, Table 1 shows all taxes and detailed information. It should be noted that FT in China generally refers to the sum of refined oil CT, VAT and related surtaxes.

Table 1: Summary of Relevant Taxes and Their Features in China's Automotive Industry

\begin{tabular}{|l|l|l|l|l|}
\hline Phase & Category & Tax Distribution & Tax-payer & Remark \\
\hline \multirow{3}{*}{ Producing } & VAT & $\begin{array}{l}\text { Central } \\
\text { government }\end{array}$ & $\begin{array}{l}\text { Automakers } \\
\text { engine displacement from 1\% } \\
\text { to 40\% }\end{array}$ \\
\cline { 2 - 5 } & $\begin{array}{l}75 \% \text { and 25\% } \\
\text { belong to central } \\
\text { and local } \\
\text { government } \\
\text { respectively }\end{array}$ & Automakers & $\begin{array}{l}\text { Circulation tax on vehicles } \\
\text { and fuel, with 17\% of balance } \\
\text { between input and output }\end{array}$ \\
\cline { 2 - 6 } & Corporate IT & $\begin{array}{l}60 \% \text { and } 40 \% \\
\text { belong to central } \\
\text { and local } \\
\text { government } \\
\text { respectively }\end{array}$ & Automakers & $\begin{array}{l}25 \%{ }^{*} \text { of total profit volume } \\
\text { after tax-paying adjustment }\end{array}$ \\
\hline
\end{tabular}




\begin{tabular}{|c|c|c|c|c|}
\hline & $\begin{array}{l}\text { Urban } \\
\text { maintenance } \\
\text { and } \\
\text { construction } \\
\text { surtax } \\
\text { (UMCS) }\end{array}$ & Local government & Automakers & $\begin{array}{l}\text { levy from individuals and } \\
\text { companies who pay } \\
\text { circulation tax, with } 7 \% \text { as } \\
\text { the urban tax rate, } 5 \% \text { as } \\
\text { country and town tax rate and } \\
1 \% \text { as others' tax rate of } \\
\text { relevant tax revenue }\end{array}$ \\
\hline & $\begin{array}{l}\text { Education } \\
\text { surtax (ES) }\end{array}$ & Local government & Automakers & $\begin{array}{l}\text { levy from individuals and } \\
\text { companies who pay } \\
\text { circulation tax, with } 3 \% \text { as } \\
\text { tax rate }\end{array}$ \\
\hline & $\begin{array}{l}\text { Estate property } \\
\operatorname{tax}\end{array}$ & Local government & Automakers & $\begin{array}{l}1.2 \% \text { of real estate residual or } \\
12 \% \text { of rent annually }\end{array}$ \\
\hline & $\begin{array}{l}\text { City and town } \\
\text { land use tax } \\
\text { (CTLUT) }\end{array}$ & Local government & Automakers & $\begin{array}{l}\text { Verified by administrative } \\
\text { areas, and levy from } ¥ 0.6 \\
(\$ 0.1) \text { to } ¥ 30 \quad(\$ 4.9) \text { per } \\
\text { square meter annually }\end{array}$ \\
\hline Purchasing & VPT & $\begin{array}{l}\text { Central } \\
\text { government }\end{array}$ & Consumers & $10 \%^{* *}$ of vehicle price \\
\hline Retaining & VVT & Local government & Consumers & $\begin{array}{lr}\begin{array}{l}\text { Charged } \\
\text { governments, by }\end{array} & \text { local } \\
\text { engine displacement } & \text { by } \\
\end{array}$ \\
\hline \multirow{4}{*}{ Using } & $\begin{array}{l}\text { CT } \quad \text { (refined } \\
\text { oil) }\end{array}$ & $\begin{array}{l}\text { Central } \\
\text { government }\end{array}$ & Consumers & $\begin{array}{l}\text { Circulation tax, with } ¥ 1.52 \\
(\$ 0.25) / \mathrm{L} \text { on gasoline and } \\
¥ 1.2(\$ 0.2) / \mathrm{L} \text { on diesel }\end{array}$ \\
\hline & VAT & Ditto & Consumers & Ditto \\
\hline & UMCS & Ditto & Consumers & Surtax of VAT on refined oil \\
\hline & ES & Ditto & Consumers & Surtax of VAT on refined oil \\
\hline
\end{tabular}

* On March 16, 2007, Enterprise Income Tax Law of the People's Republic of China was issued, with identified qualified high and new tech enterprises enjoying preferential tax rate of $15 \%$ of IT;

**VPT base is vehicle price with removal of VAT

China's tax preferences for NEV, namely Plug-in Hybrid Electric Vehicles (PHEV), Battery Electric Vehicles (BEV), and Fuel Cell Electric Vehicles (FCEV), include free CT, free VPT and free VVT. Firstly, BEVs are regarded as zero-displacement, thus can be free of vehicle CT which is rated in terms of vehicle displacement. Secondly, according to Announcement on the Exemption of VPT on NEV jointly issued by Ministry of Finance, the State Administration of Taxation and the Ministry of Industry and Information Technology of China, BEVs (lead acid battery excluded), PHEV (including range-extended models) and FCEVs that meet corresponding qualifications are free of VPT from September 1, 2014 to December 31, 2017. Tax-free models need to pass specified examination concerning electric range and comprehensive fuel consumption is used as standards. Thirdly, energy efficient and NEV can be free of VVT or exempted half of VVT after approval by the State Council.

\section{Scenario Analysis of Tax Burden}

\section{Tax Burden at Purchasing Phase}

Chinese consumers lack understanding of taxes at purchasing and using phases, and scarcely pay attention to taxes within price such as vehicle CT. Actually, vehicles with different displacements pay different CT, and CT is included in ex-factory price, incorporating into the bases of VAT and surtaxes. Thus, CT and VAT are included in Manufacturers' Suggested Retail Prices (MSRP). Besides, the amount of VPT paid by consumers is $10 \%$ of vehicle price exempted of VAT. For further illustration, consumers' actual tax burden ratio at purchasing phase is calculated as shown in 
Table 2. 'Tax within price' represents the ratio of taxes in MSRP. 'Actual tax burden' represents the ratio of all taxes in total purchasing cost consisting of VPT and MSRP.

It is shown that tax burden of largedisplacement vehicles is obviously larger than mid-displacement and smalldisplacement models. Purchasing tax burden of $4.0 \mathrm{~L}$ or above models is 2.4 times that of $1.5 \mathrm{~L}$ models. However, for models with $1.0 \mathrm{~L}$ or below displacement, there is no obvious reduction for purchasing tax burden seeing that there are little differences between tax burden ratio of middle-displacement and small- displacement models. On the other side, according to the production and sales volume of domestic manufactured models in Chinese PV market in the first quarter of 2015, models with displacements between $1.0 \mathrm{~L}-2.0 \mathrm{~L}$ occupy over $90 \%$ of the market share (CAAM, 2015). Among the range, purchasing tax burden is $24.88 \%(1.0 \mathrm{~L}<$ Displacement $\leq 1.5 \mathrm{~L})$ and $26.50 \%(1.5 \mathrm{~L}<$ Displacement $\leq 2.0 \mathrm{~L}$ ) respectively. Such a narrow gap in between proves the comparatively limited adjustment function of taxes at purchasing phase on consumption market in terms of energy conservation and emission reduction, showing weak encouragement on small or mini cars.

Table 2: PV Tax Burden when Purchasing

\begin{tabular}{|c|c|c|}
\hline Displacement(D) & Tax within price (\%) & Actual tax burden (\%) \\
\hline$D \leq 1.0 \mathrm{~L}$ & 16.67 & 23.20 \\
\hline $1.0 \mathrm{~L}<\mathrm{D} \leq 1.5 \mathrm{~L}$ & 18.49 & 24.88 \\
\hline $1.5 \mathrm{~L}<\mathrm{D} \leq 2.0 \mathrm{~L}$ & 20.30 & 26.50 \\
\hline $2.0 \mathrm{~L}<\mathrm{D} \leq 2.5 \mathrm{~L}$ & 23.91 & 29.84 \\
\hline $2.5 \mathrm{~L}<\mathrm{D} \leq 3.0 \mathrm{~L}$ & 26.61 & 31.93 \\
\hline $3.0 \mathrm{~L}<\mathrm{D} \leq 4.0 \mathrm{~L}$ & 38.12 & 42.12 \\
\hline $\mathrm{D}>4.0 \mathrm{~L}$ & 51.10 & 59.71 \\
\hline
\end{tabular}

\section{Overall Tax Burden}

To calculate total taxes in the whole life cycle, this paper chose the best-selling 23 models in Chinese PV market in 2014 as a case study (with similar brand positions to avoid too much price premium), covering displacement range from $1.0 \mathrm{~L}$ to $4.6 \mathrm{~L}$. It is assumed that all models drive $18,000 \mathrm{~km}$ per year (Huo et al., 2012), with life cycle of 6 years (Hao et al., 2011). Calculated tax burden in all phases include vehicle CT, VAT, UMCS, educational surtax, VPT, VVT and refined oil CT (oil price is assumed as $¥ 7.5 / \mathrm{L}$, or $\$ 1.2 / \mathrm{L}$ ). Since all of the models are domestically manufactured, CTLUT and tariff of imported vehicles are not included.

For simplicity, models of the same displacement, with similar price and fuel consumption are integrated as one. There end up with 15 typical cases, as shown in Fig. 1. Generally speaking, with the increase of displacement, the total amount of tax burden in the 6-year use grows continuously, while the ratio of tax burden to vehicle price firstly decreases and then increases. It makes sense that absolute tax burden increases as vehicle CT and VVT are higher for larger displacement. 


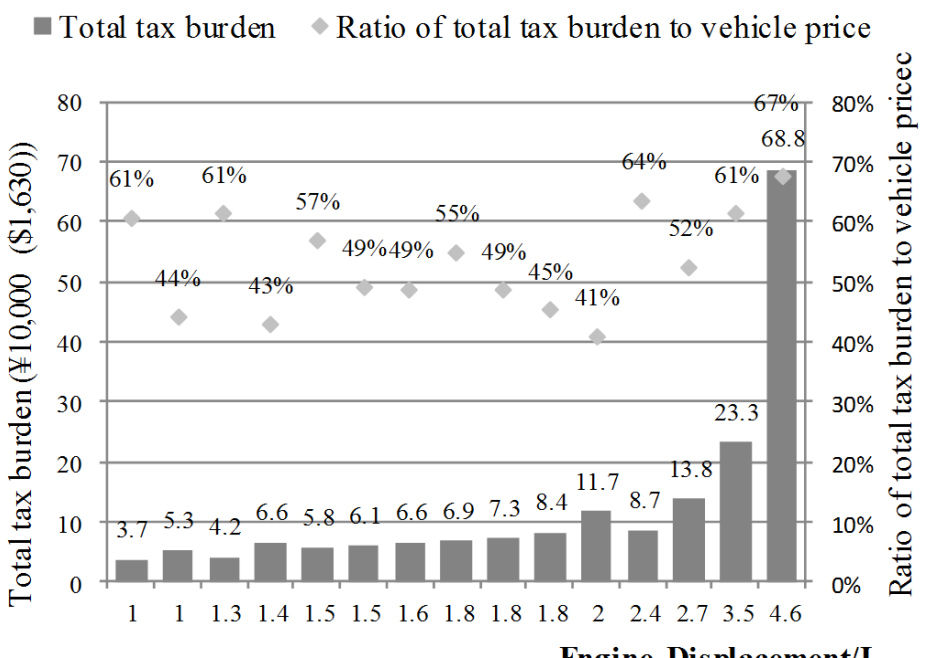

Fig. 1: Tax Burden in the Whole Life Cycle

Besides, large-displacement models are more fuel consuming so as to have heavier FT burden. However, seeing from the tax burden ratio, vehicles with $1.0 \mathrm{~L}$ and $1.3 \mathrm{~L}$ displacement are in the same level as models with 3.5L displacement, and are higher than models with displacement between $1.6 \mathrm{~L}$ and $2.0 \mathrm{~L}$, which is not reasonable. This is due to the fact that the gap of fuel consumption per hundred kilometers between middle and small displacement models is not significant, and the slightly lower FT burden is not comparable to much lower vehicle price, which mathematically increases total tax burden ratio of small-displacement models. In all, under the current automotive tax scheme in China, the total tax burden ratio of small-displacement models is approximately the same as largedisplacement models, and middisplacement models benefit the most, which is clearly against the strategic direction of energy conservation and emission reduction.

\section{Tax Burden across Different Phases}

The tax burden of the above 23 models was averaged and summarized according to different phases, namely the purchasing, retaining and using phase from consumers' perspective. Results show that the average tax burden at purchasing phase is $¥ 67,800$
$(\$ 11,040)$ accounting for $69 \%$ of total tax burden in the whole life cycle, while tax burden at retaining phase is $¥ 4400$ (\$716) accounting for $4 \%$ and tax burden at using phase is $¥ 26,800(\$ 4,363)$ accounting for $27 \%$. It is thus clear that tax chain of Chinese automobile products is heavily unbalanced throughout the life cycle at different phases, with producing and purchasing tax burden exceeds two thirds of the total tax burden, as shown in Fig. 2.

Compared with developed countries, Chinese vehicle users' total tax burden is lower than that of Japan and the UK, similar to that of Germany but far higher than the U.S.A (JAAM, 2014; Wang et al., 2015). Seeing from tax income structure, there are more categories of taxes in China than other countries. In addition, it is worth noted that MVT and tonnage tax levied at retaining phase of Japan accounts for $77.5 \%$ of the total tax. Retaining tax of the UK accounts for $49.3 \%$ and that of Germany is $43.4 \%$, while retaining tax (VVT) in China only covers $17.2 \%$ (JAAM, 2014; Wang et al., 2015), which demonstrates again that China's automotive tax burden is over-assigned to purchasing phase. This is partly due to China's low FT rate. The refined oil CT in China has been raised twice at oil price recession in 2014, and currently China levies by volume at quota, with $¥ 1.52 / \mathrm{L}$ 
$(\$ 0.25 / \mathrm{L})$ for gasoline and $¥ 1.2 / \mathrm{L}(\$ 0.2 / \mathrm{L})$ for diesel, which is roughly $20 \%$ of the price and still very low globally. Taxes generally account for $70 \%$ to $80 \%$ of oil price in EU countries (Jenn et al., 2015). Germany has high FT, and its FT income not only covers the expenditure of road construction, but also pays for retirement pension (Tscharaktschiew, 2014). Even so, some scholars still think that there is room for German's FT growth of at least 48\% (Gomez and Vassallo, 2013). Besides, Japan levies special tax of 53.8 yen/L and 8\% CT for gasoline (Jenn et al., 2015). According to the oil price in the Japanese market in January 2015 (Xinhua Net Japan, 2015), tax rate for ordinary gasoline is appropriately $47 \%$. In effect, FT is the important economic leverage to increase fuel economy globally. Reasonable FT can reduce use overhead with vehicles having higher fuel efficiency, which encourages the consumption of fuel saving vehicles. Meanwhile, it is typical to strengthen the levying of FT to control vehicles' lowefficient use under the principle of 'ownership encouraged and usage rationalized' like Japan and Singapore.

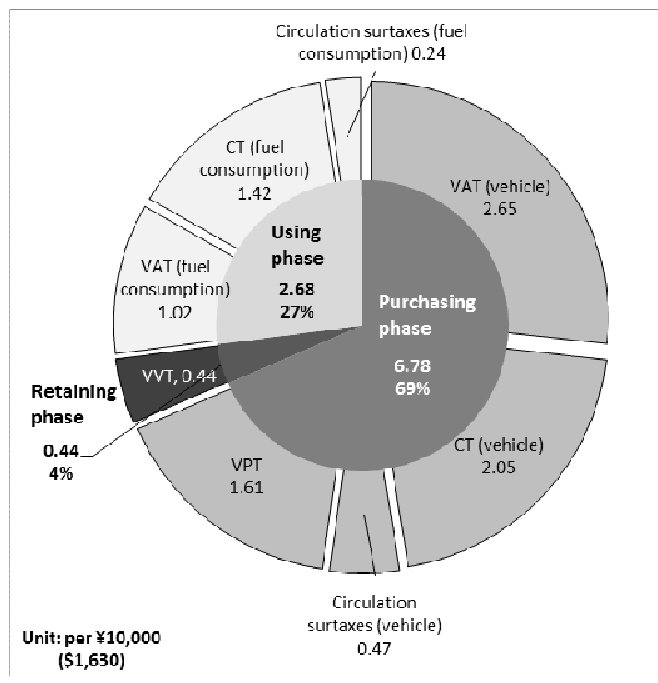

Fig. 2: Average Tax Burden of Chinese PVs at all Phases

\section{Distribution Mechanism of Tax Income}

\section{Distribution among Central and Local Governments}

The legislated tax income allocation between central and local governments can be seen according to Table 1 . In addition, central finance will return certain tax to local finance including VAT\&CT return and IT based return. Clearly shown in Table 3, although local governments enjoy most of these tax categories, those taxes with higher income are mostly occupied by central government. After tax return, actual central income in 2014 still accounts for $72 \%, 2.6$ times of local governments' income. It can be seen that central government obtains most of direct tax in automobile manufacturing industry, having much bigger financial power.

On the other hand, local tax income will be distributed between manufacturing and using areas (usually also the purchasing areas). The exact distribution ratio shows that the income of the manufacturing area is 3 times of that of using area, leaving out FT. As mentioned, automotive taxes are over-assigned to producing phase; therefore, manufacturing areas enjoy most of local governments' revenue, including local part of IT and domestic VAT as well as total UCMT, ES and CTLUS. Meanwhile, using areas only obtain limited revenue from VVT and FT, getting nothing from vehicle CT, VPT and refined oil CT. It is suggested to backward automobile CT 
levying, adjust VPT as local tax, and endow local governments the privilege to set up FT (Zhang, 2015).
Overall, distribution pattern among central and local governments is not well balanced, benefiting most to central government and least to using area. Meanwhile, further transparency is required in the mechanism.

Table 3: Direct Tax Distribution Pattern in 2014*

\begin{tabular}{|l|r|r|r|r|r|r|}
\hline $\begin{array}{l}\text { Unit: ¥ 1 billion } \\
\text { \$160 million) }\end{array}$ & $\begin{array}{l}\text { Central } \\
\text { (after } \\
\text { return) }\end{array}$ & \multicolumn{1}{|l|}{ Ratio } & $\begin{array}{l}\text { Local } \\
\text { (manufacturing } \\
\text { areas) }\end{array}$ & Ratio & $\begin{array}{l}\text { Local } \\
\text { (using } \\
\text { areas) }\end{array}$ & Ratio \\
\hline VPT & 288.5 & $100 \%$ & 0.00 & $0 \%$ & 0.0 & $0 \%$ \\
\hline Domestic VAT & 100.0 & $65 \%$ & 54.1 & $35 \%$ & 0.0 & $0 \%$ \\
\hline Enterprise IT & 56.9 & $56 \%$ & 44.1 & $44 \%$ & 0.0 & $0 \%$ \\
\hline Vehicle CT & 84.0 & $90 \%$ & 9.4 & $10 \%$ & 0.0 & $0 \%$ \\
\hline VVT & 0.0 & $0 \%$ & 0.0 & $0 \%$ & 54.1 & $100 \%$ \\
\hline UMCS & 0.0 & $0 \%$ & 14.1 & $99.6 \%$ & 0.1 & $0.4 \%$ \\
\hline Personal IT & 0.0 & $0 \%$ & 11.3 & $100 \%$ & 0.0 & $0 \%$ \\
\hline ES & 0.0 & $0 \%$ & 6.0 & $99.6 \%$ & 0.0 & $0.4 \%$ \\
\hline CTLUT & 0.0 & $0 \%$ & 3.7 & $100 \%$ & 0.0 & $0 \%$ \\
\hline $\begin{array}{l}\text { Estate property } \\
\text { tax }\end{array}$ & 0.0 & $0 \%$ & 3.2 & $100 \%$ & 0.0 & $0 \%$ \\
\hline Stamp tax & 0.0 & $0 \%$ & 2.1 & $100 \%$ & 0.0 & $0 \%$ \\
\hline Business tax & 0.0 & $0 \%$ & 0.8 & $0 \%$ & 0.8 & $100 \%$ \\
\hline Others & 0.0 & $0 \%$ & 3.0 & $100 \%$ & 0.0 & $0 \%$ \\
\hline Sum & 529.4 & $\mathbf{7 2 \%}$ & 151.0 & $\mathbf{2 1 \%}$ & 55.0 & $\mathbf{7 \%}$ \\
\hline
\end{tabular}

* Original Data Source: 2015 China Taxation Yearbook (SAT, 2015)

The analysis only considers direct tax in automotive manufacturing industry, excluding tax in upstream and downstream industries and import/export links.

\section{Financial Power and Administrative Duties}

It is reasonable for each governing entity to have financial power and administrative duties that match with each other. The last section clearly shows the unbalanced financial power with tax revenue. In terms of administrative duties, road construction and maintenance fees are basic construction expenditure in automotive industry, where local governments have higher responsibility and local finance acts as the major undertaker. In 2014, the revenue and expenditure gap of charging highways, which accounts for only $3.6 \%$ of total mileage of all roads, is $¥ 157.1$ billion ( $\$ 26$ billion) (Liu et al., 2016). It is in the similar scale to direct tax income of automotive manufacturing industry in local finance. Obviously local governments are not able to undertake the road construction and maintenance fees. Actually, except for this, local governments need to undertake expenditures of governing environmental pollution, traffic congestion and insufficient parking lots, and they are real undertakers of solving social concerns about automotive industry. Consequently, there exist imbalance of financial power and administrative duties between central and local governments.

On the other side, Table 3 shows that approximately three fourths of local tax revenue in automotive industry is dedicated to manufacturing area, which merely needs to take care of short-time monitoring about concentrated factory pollution during production. However, the complex management issues during vehicle using phase are undertaken by governments in using area, who only benefit from $1 / 14$ of total tax revenue yet 
face all-round traffic and environmental issues. Long-term management and continuous investment are required to effectively address such concerns. Apparently, there is also imbalance of financial power and administrative duties between manufacturing and using areas. Under the current automotive tax scheme, local governments would strive to be manufacturing area, so as to obtain more and undertake less. Additionally vehicle factories can significantly raise local GDP (Gross Domestic Product), which promotes local governments even further. In order to gain advantages of inviting automaker's investments, local governments usually offer low-cost land and adopt fiscal rebate or subsidized loan to compete with other regions. However, this is not beneficial for reasonable industrial layout nationwide and can even derive risk of excessive production capacity, which is a big headache of China's current situation. For governments in using areas, lacking of industrial tax revenue push them to use simple and direct administrative measures such as vehicle plate restriction or traffic control to address congestion and environmental issues, instead of actively improve relevant infrastructure and continuously optimize urban planning. Those mainstream administrative measures cannot really ease congestion nor parking difficulty, at the sacrifice of both people's mobility freedom and a healthy development of automotive industry.

Obviously, to establish an energy efficient and harmonious automotive society in future, a set of comprehensive systematic solutions are in urgent need to stop some cities from interestingly encouraging automotive production and restricting vehicle consumption or usage at the same time. Earmarking taxes may be put into practice to well balance between governments' financial power and administrative duties.

\section{Proposals for Optimization}

Ideal automotive tax scheme shall advance a healthy development of automotive industry, as well as guarantee a harmonious automotive society. Based on the above qualitative discussions and quantitative analysis, the future direction to optimize China's automotive tax scheme can be expected as the following five suggestions and prospects.

First, strengthen the guiding role of automotive taxes to pose more incentives to low-engine-displacement vehicle purchase. Large-displacement vehicles should be levied with heavy tax burden while systematic approaches of tax reduction or exemption on smalldisplacement (such as $1.3 \mathrm{~L}$ or below) vehicles should be carried out. This is due to the fact that under the same resource conditions, small-displacement vehicles can help more Chinese possess a vehicle. Additionally, this is definitely beneficial for the promotion of energy conservation and emission reduction heading towards sustainable development of automotive industry.

Second, set up automotive tax scheme with the principle of 'ownership encouraged and usage rationalized' to optimize the share of automotive tax revenue at all phases. It is necessary to assign more tax burden at using phase, through either reducing taxes at purchasing phase moderately or increasing taxes at using phase such as FT. Gradually, a comprehensive tax system based on fuel consumption and carbon emission should be established. Currently the over-assignment at purchasing phase potentially leads to excessive using, resulting in heavier environmental pollution and more serious traffic congestion. China can learn from other countries' approach to set up a more reasonable and comprehensive evaluation system for vehicle's energy conservation and emission reduction effect, and make it as the major reference to levy automotive taxes. There is no doubt that it will play an important role in initiating the whole society to adopt greener and more sustainable using approach.

Third, implement the principle of 'earmarking taxes and burdening beneficiaries' with the support of strict monitoring mechanism. Much experience 
can be borrowed from Japan. Focusing automotive tax revenue usage on road construction, urban planning and parking facilities expansion to strengthen the overall infrastructure will effectively help relieve traffic congestion and parking difficulties. It is also reasonable to distribute automotive taxes to scientific innovation and research platform to promote progress and upgrading of relevant technologies. Moreover, 'burdening beneficiaries' is a common practice to embody social equality.

Fourth, gradually and adequately decentralize taxation power to local governments. There exists many differences in local economic development, industry structure and tax income structure, thus a unified automotive tax scheme may not have the best universal effects. Central government can consider giving local government moderate tax rate adjustment privilege or even the power to set up a tax, so as to make the most use of market leverage role of taxation. For example, economically developed regions can set up congestion tax accordingly to ease traffic pressure with economic approaches. Meanwhile, local people's congress shall play its role in monitoring to ensure that congestion tax is truly used to solve traffic congestion. In this sense, reasonable automotive taxation reform can fully lead to a new approach to solve congestion and environmental issues for local governments.

Fifth, balance distribution ratio of automotive tax revenue among central and local governments, in order to provide necessary financial support for local governing of social concerns in automotive industry. Related taxes at retaining and using phases should mainly be distributed to local fiscal revenue while local governments' tax benefits at producing phase shall be weakened. Central government can also consider distributing automotive tax revenue according to the amount of local vehicle consumption. In this case, not only local government's dedicated investment invitation trials, which may lead to production capacity overlapping or unreasonable industry layout, can be weakened, but also financial support can be ensured to motivate local governments to address social concerns in automotive industry positively. In the end, a well balance of financial power and administrative duties should be achieved nationwide.

\section{Conclusion}

China's existing automotive tax scheme has obvious demerits without necessary role of taxation adjustment. Therefore, taxation's optimization has become the significant reform direction under the blueprint of 'China Manufacturing 2025'. This paper comprehensively analyzes related issues of China's automotive tax scheme, and comes up with detailed prospects for future improvement, from the strategic perspective of supporting a stronger automotive country setup. The findings suggest that central government must have a comprehensive and systematic consideration and make the overarching design, among which tax scheme can and should be one of the important approaches. It is acknowledged that this paper lacks solid statistical foundation like most empirical studies. However, based on this study, further researchers can make more depth analyses on five raised proposals to optimize China's automotive tax scheme.

\section{Acknowledgment}

This study is sponsored by the Chinese Academy of Engineering through two succeeded projects (2013-ZD-04, 2015-ZD-07) and the National Natural Science Foundation of China (71403142).

\section{References}

1. CAAM (China Association of Automobile Manufacturers). (2010) 'Release of 2009 Automotive Sales and Economic Performance', CAAM Statistical Information Net. [Online], [Retrieved December 25, 2016], http://www.autostats.org.cn/ReadArticle.asp?NewsID=6234

2. CAAM (China Association of Automobile Manufacturers). (2015) Statistical Summary of Production and Sales in 
Chinese Automotive Industry, CAAM, Beijing.

3. Chen, XZ and Zhou, XD. (2010), 'Analysis of developing characteristics of China's automotive tax and fees'. Modern Business Trade Industry, 22(7), 63-64.

4. Downs, A. (2000), Stuck in traffic: Coping with peak-hour traffic congestion, Brookings Institution Press.

5. Duncan, D. and Graham, J. (2013), 'Road user fees instead of fuel taxes: The quest for political acceptability', Public Administration Review, 73 (3), 415-426.

6. Gomez, J. and Vassallo, JM. (2013), 'Comparative analysis of road financing approaches in Europe and the United States', Journal of Infrastructure Systems, 20 (3), 04014008.

7. Greene, DL. (2011), 'What is greener than a VMT tax? The case for an indexed energy user fee to finance us surface transportation', Transportation Research Part D: Transport and Environment, 16 (6), 451-458.

8. Hao, H., Wang, H., Oouyang, M. et al. (2011), 'Vehicle survival patterns in China', Science China Technological Sciences, 54 (3), 625-629.

9. Huo, H., Zhang, Q., He, K. et al. (2012), 'Vehicle-use intensity in China: Current status and future trend', Energy Policy, 43, 436-16.

10.JAMA (Japan Automobile Manufacturers Association). (2014) 'International comparison of the motor vehicle taxes', Japan Automobile Manufacturers Association Inc. [Online], [Retrieved December 25, 2016], http://www.jamabj.cn/tax/responsibility/i mage_01.asp

11.Jenn, A., Azevedo, IL. and Fischbeck, P. (2015), 'How will we fund our roads? A case of decreasing revenue from electric vehicles', Transportation Research Part A: Policy and Practice, 74, 136-147.
12.Li, J. (2009), 'Research on tax policy to guide the vehicle consumption of the public', Social Science Journal, 2009 (3), 97 101.

13.Li, XL. and Wang, BP. (2009), 'Fuel tax reform is the strategic choice to promote energy conservation and emission reduction as well as the scientific development', Taxation Research, 2009 (1), 48-50.

14.Lian, GP. and He, RL. (2005), “China's private car consuming and taxation adjustment", Taxation Research, 2005 (1), 94-94.

15.Liu, ZC. and Liu, R. (2010), 'Research on the Improvement of the consumption tax system based on the reflection of traffic and vehicle 'tax reform' ', Taxation Research, 2010 (8), 34-38.

16.Liu, ZW., Wang, Y., Hao, H. et al. (2016), 'Distribution Mechanism and Reform Strategy of Tax Income in Automotive Industry in China', Taxation and Economy, 2016 (2), 1-9.

17.Mcmullen, BS., Zhang, L. and Nakahara, K. (2010), 'Distributional impacts of changing from a gasoline tax to a vehiclemile tax for light vehicles: A case study of Oregon', Transport Policy, 17 (6), 359-366.

18.Parry, IW. and Small, KA. (2005), 'Does Britain or the United States have the right gasoline tax?', The American Economic Review, 95 (4), 1276-1289.

19.SAT (State Administration of Taxation). (2015), China Taxation Yearbook 2015, Chinese Taxation Press, Beijing

20.Talukdar, MH. (2013), 'Framework for Traffic Congestion Management', Economia. Seria Management, 16 (1), 54-64.

21.Tscharaktschiew, S. (2014), 'Shedding light on the appropriateness of the (high) gasoline tax level in Germany', Economics of Transportation, 3 (3), 189-210. 
22.Vasudevan, V. and Nambisan, SS. (2013), 'Impacts of energy regulations and vehicular technologies on fuel tax revenues', Journal of Infrastructure Systems, 20 (2), 04014007.

23.Wang, Y., Liu, ZW., Hao, H. et al. (2015), 'Strengthening China's Automotive Industry: The Taxation Perspective', Proceedings of the Eleventh International Symposium on Global Manufacturing and China, ISBN: 978-1-902546-53-7, 5-6 September 2015, Hangzhou, China, 87-91.

24.Xiao, JT. (2008), 'Research on automotive tax scheme reform', Hubei Social Sciences, 2008 (4), 113-115.
25.Xinhua Net Japan. (2015) 'Japan's Domestic Retail Price of Gasoline Decreased to 130 Yen', Xinhua Net. [Online], [Retrieved March 1, 2017], http://japan.xinhuanet.com/201501/30/c_133958127.htm

26.Yuan, HR. (2008), 'Environment Analysis of Tax Policies on Automobile Industry in China: a Macroscopical Angle of View Based on Adjustment of Tax System', Taxation and Economy, 2008(1), 87-90.

27.Zhang, X. (2015), 'Suggestions on China's tax policies', Finance and Accounting Monthly, 2015 (8), 18. 